\title{
QUESTIONNAIRE
}

STUDY TITLE:A teachers' perspective on School-based HPV Vaccination in Kitui County: Knowledge, Acceptability, Barriers and Opportunities

\section{SCHOOL DETAILS:}

1. Name of your school:

2. Type of Institution:

3. Location of School:

$\square$ Public

$\square$ Private

DEMOGRAPHICS:

Please fill in the following information about yourself:

4. What is your age? Years.Date of Birth: (Year)

5. Sex: $\square$ Male $\square$ Female

6. Position:

$\square$ Head-teacher

Deputy Head-teacher Teacher Other (specify):

7. Level of education attained so far:

$\square$ KCSE

Diploma

Rural 
12. Are you aware that all standard four girls in Kitui County are being offered a Human Papillomavirus (HPV) vaccine? $\square$ Yes $\quad \square$ No

If YES, how did you hear about it? (Tick all that apply)

$\square$ from Fellow teachers

On Radio

from Education Officials

On Television

from Health Officials

Other (specify):

13. Who lead the HPV vaccine awareness campaign in your area?

Ministry of Health Officials

Ministry of Education Officials

County Government Officials

Don't Know

Other:

14. Who would you prefer to lead such an awareness campaign in the future?

Ministry of Health Officials

Ministry of Education Officials

County Government Officials

I don't know

Other (specify):

15. Did your school participate in the HPV vaccine awareness campaign?

YES

NO

I don't know

If YES, who was involved in the awareness activities? (Tick any/all that apply)

Pupils

Parents

Teachers

Head-teacher/ Deputy Head-teacher

Other (specify): 
16. (a) Did your school get any promotional materials (brochures, posters, pamphlets, etc) on HPV?

$\square$ YES $\quad \square$ NO $\square$ I don't know

(b) If YES, what did the material contain? (Tick any/all that apply)

$\square$ Information on transmission of HPV

$\square$ Information on diseases caused by HPV

$\square$ Information on prevention of HPV

$\square$ Information on HPV vaccine

$\square$ Information on Cervical Cancer

$\square$ Don't Know

$\square$ Other (specify):

(c) Do you feel the content in these materials was sufficient?

Sufficient $\quad \square$ Insufficient $\quad \square$ Don't Know

Other (specify)

17. Did you attend any seminar or training on HPV Vaccine?
YES
NO
$\square$ Other (specify):

18. What diseases does HPV Vaccine protect against (tick any/all that apply).

Cervical Cancer

Anal Cancer

Other (specify):

Vulvar Cancer

Warts

HIV/AIDS

Breast cancer 
19. What is the mode of transmission of HPV? (Tick any/all that apply)

Physical contact

Aerosol/Air droplet

Sexual intercourse

Other (specify):

20. Which of the following persons can be infected by HPV?

$\square$ Male $\quad \square$ Female $\quad \square$ Both $\square$ I don't know

21. Nearly everyone infected with HPV will have symptoms:
True
$\square$ False
Don’t Know

22. Infection with HPV may lead to cervical cancer:
$\square$ True
False
Don’t Know

23. Cervical cancer is a leading cause of cancer deaths in women in Kenya:
True
$\square$ False
$\square$ I Don’t Know

24. Have you heard about Pap smear test?
$\square$ Yes
$\square$ No
Other (Specify):

25. What is a Pap Smear test used for?

$\square$ Testing sexually transmitted diseases (STDs)

$\square$ Treating Cervical Cancer

$\square$ Cervical cancer Screening

26. There is no need for Pap smear screening after receiving HPV vaccination
$\square$ True
False
Don't know

27. Would you allow your daughter or a close relative to get HPV Vaccination?

$\square$ YES

$\square \mathrm{NO}$

I am not sure

If your answer is NO, please indicate why?

I am against all Vaccinations

The Vaccine is not safe

$\square$ The vaccine will make young girls start sexual activity early

My religion does not allow vaccination

$\square$ The HPV vaccine is not necessary

$\square$ Other (specify): 
28. What was the effect of vaccine- related activities on daily school/educational activities?

$\square$ No disruption $\quad \square$ Minimal disruption $\quad \square$ A lot of disruption $\square$ Other (Specify):

29. Which of these delivery system do you think is appropriate for vaccine delivery

$\square$ Schools

$\square$ Health facilities/clinics

$\square$ Community (village market, churches)

$\square$ Other (Specify):

For the following section, please indicate whether you agree or disagree with the statement:

\begin{tabular}{|l|l|l|l|}
\hline & Agree & Neutral & Disagree \\
\hline 30. All standard 4 girls should get the HPV Vaccine & & & \\
\hline 31. HPV Vaccine is safe & & & \\
\hline 32. HPV infection is common in Kenya & & & \\
\hline $\begin{array}{l}\text { 33. I have enough information about HPV vaccine to } \\
\text { guide my pupils }\end{array}$ & & & \\
\hline 34. I would like to know more about the HPV vaccine & & & \\
\hline 35. Standard 4 girls should get education about sex & & & \\
\hline 36. Vaccine-related activities eat too much of my & & & \\
teaching time & & & \\
\hline 37. School-based vaccination of children should be \\
continued
\end{tabular}


38. In your own view do you think HPV vaccination to standard four girls was successful in Kitui?

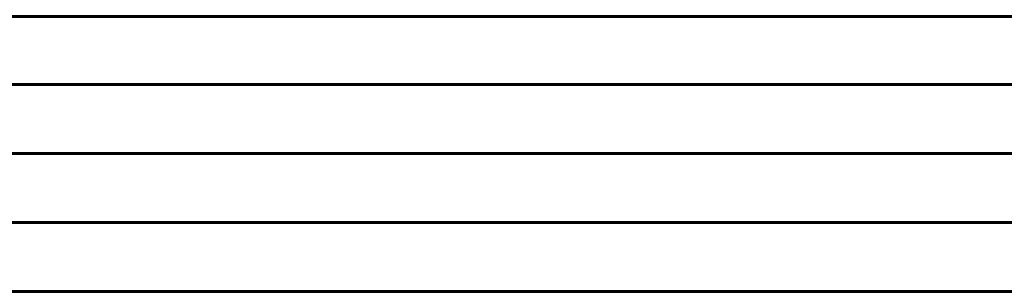

39. What in your opinion hindered the vaccination exercise in primary schools in Kitui?

40. What do you think can be done to improve the vaccination exercise in primary schools?

**END OF QUESTIONNAIRE . Thank you for your time** 